\title{
Postharvest quality of tomato fruits bagged with nonwoven fabric (TNT)
}

\section{Calidad poscosecha de los frutos de tomate embolsados con textil no tejido (TNT)}

\section{PATRIK LUIZ PASTORI ${ }^{1,3}$ \\ ROSENYA MICHELY CINTRA FILGUEIRAS' \\ ANDRÉIA HANSEN OSTER ${ }^{2}$ \\ MARIANNE GONÇALVES BARBOSA ${ }^{1}$ \\ MÁRCIA RÉGIA SOUZA DA SILVEIRA² \\ LORENA GOMES GIRÃO PAIVA'}

Fruits bagged with nonwoven

fabric.

Foto: P.L. Pastori

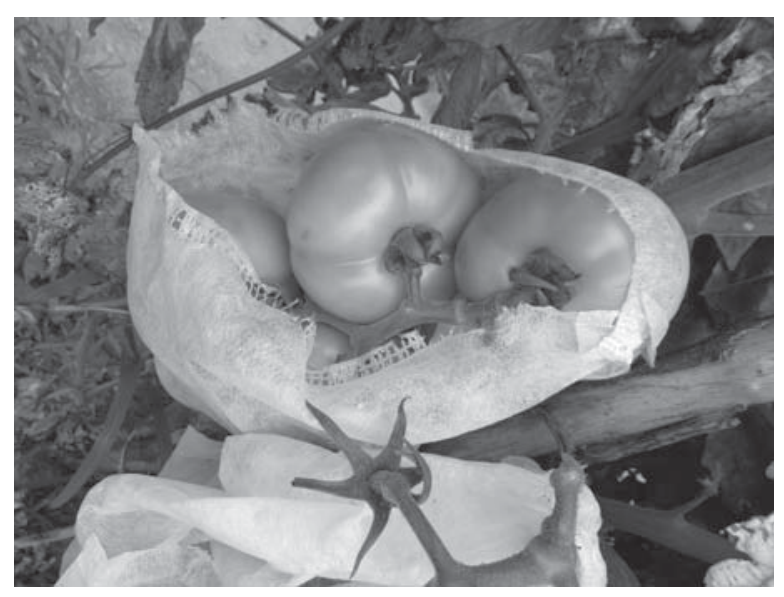

\begin{abstract}
The possibility of cultivation without the use of chemical insecticides or reduction thereof, associated with the requirements of consumers has motivated growers to return to the practice of bagging fruit, but it is possible that this technique causes changes in the visual and organoleptic characteristics of fruits. The objective of this study was to evaluate possible changes in postharvest characteristics in 'Valerin' tomato fruits produced inside nonwoven bags (TNT) and validate the best period for bagging. The fruits came from commercial cultivation of tomato plants, located in "Ubajara", "Ceará" State, Brazil. The experiment design used $2 \times 4$ factorial randomized blocks with five repetitions. The factors considered two types of insecticide use: 1-Plants treated with insecticides and 2-Plants not treated with insecticides, and four ways to bag the bunches with nonwoven fabric (TNT): T1-Bagging flower, T2-Bagging the bunches with fruits with a $1.5 \mathrm{~cm}$ diameter, T3-Bagging the bunches with fruits with a $3.0 \mathrm{~cm}$ diameter, and T4-Bunches not bagged (control). Variations in color parameters (brightness and hue angle) and firmness did not compromise the fruit quality when bagging was conducted in the flower stage (T1) or when the fruits had a $1.5 \mathrm{~cm}$ diameter (T2). The other parameters (titratable acidity, total soluble solids, total carotenoids, lycopene and B-carotene) showed no change when compared to the control. Bagging the tomato bunches in the flower stage or when the fruits had a $1.5 \mathrm{~cm}$ diameter did not change the postharvest quality.
\end{abstract}

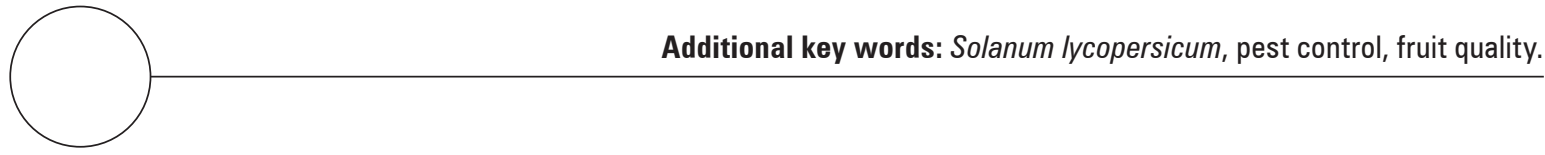

\footnotetext{
Universidade Federal do Ceará, Fortaleza, CE (Brazil).

2 Embrapa Agroindústria Tropical, Fortaleza, CE (Brazil).

3 Corresponding author. plpastori@ufc.br
} 


\section{RESUMEN}

La posibilidad de producción sin el uso de insecticidas químicos o la reducción de los mismos, asociada a las exigencias de los consumidores ha motivado a los cultivadores a volver a la práctica de embolsado del fruto, pero es posible que esta técnica cause cambios en las características visuales y organolépticas del mismo. El objetivo de este estudio fue evaluar los posibles cambios en las características poscosecha en los frutos de tomate 'Valerin' producidos dentro de las bolsas de textil no tejido (TNT) y validar el mejor período para la finalización del embolsado. Los frutos utilizados fueron de una plantación comercial de tomate, ubicada en "Ubajara", Estado de "Ceará", Brasil. El diseño experimental fue bloques al azar en factorial $2 \times 4$, con cinco repeticiones. Los factores considerados se refieren a dos formas de uso de los insecticidas: 1-Plantas tratadas con insecticidas y 2-Plantas no tratadas con insecticidas y cuatro formas de embolsar los racimos con tejido no tejido (TNT): T1-Empaqueta flor, T2-Embolsado de los racimos con frutos de 1,5 cm de diámetro, T3-Embolsado de los racimos con frutos de 3,0 cm de diámetro, T4-Racimos no embolsados (control). Las variaciones en los parámetros de color (brillo y ángulo de tono) y firmeza no comprometieron la calidad del fruto cuando se embolsaba en la etapa de flor (T1) o cuando los frutos tenían 1,5 cm de diámetro (T2). Los otros parámetros (acidez titulable, sólidos solubles totales, carotenoides totales, licopeno y ß-caroteno) no mostraron cambios en comparación con el control. Embolsar racimos de tomate cuando se realizan en la etapa de flor o cuando los frutos tienen alrededor de $1,5 \mathrm{~cm}$ de diámetro no cambia la calidad poscosecha.

Palabras clave adicionales: Solanum lycopersicum, control de plagas, calidad del fruto.

Received for publication: 10-02-2017 Accepted for publication: 15-04-2017

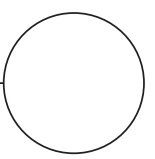

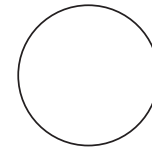

The tomato (Solanum lycopersicum L.) represents one of the most worldwide cultivated oleraceous, being, therefore considered of great economic importance. Besides having importance as a worldwide commodity, it has its space highlighted on the consumer's table (Ferreira et al., 2010). Although, it is a plant of difficult conduction, because it demands numerous culture operations, and for its susceptibility to plague attacks and pathogens (Jordão and Nakano, 2002; Herrera et al., 2015).

On the tomato production, the control of arthropods plague is performed, most of the times, through application of chemical insecticides and, when used incorrectly, might harm the establishment and development of natural enemies, causing a reduction of the biological diversity, which may provoke the appearance of new plagues and the outbreak of secondary pests (Santos et al., 2007). This model of plague control might still considerably increases the cost of production, compromise the quality of the fruits through contamination, when incorrectly performed, or even cause intoxication of the applicators in the tillage (Leite et al., 2014).

Due to the increasing demand for products free of residue contamination, a tendency of reduce insecticide use has been observed. Therefore, other less aggressive and efficient control methods are being studied (Lebedenco et al., 2007). The bagging of fruits might be an alternative for the control of borer insects, reducing the need of insecticide application (Lebedenco et al., 2007; Filgueiras et al., 2017). Thus, the bagging may, besides halting the action of insects that cause damage, diminish possible chemical residues from the application of pesticides in fruits (Leite et al., 2014). However, it is fit to highlight that this technique serves of mechanical control and preferably must not interfere on the formation and quality of the fruits, preserving their physicochemical characteristics (Silva et al., 2014).

In this sense, it is of a high priority the knowledge of the fruit maturation processes, which is very complex, genetically directed and contain a wide range of physiological and biochemical alterations that affect, among other characteristics, color, texture, taste and flavor (Ferreira et al., 2010). This process is characterized by changes on the respiration rate, ethylene production, activation of the genes that regulate the carotenoids production, on the flavor development, and, on the fruit texture (Pinheiro et al., 2007).

On the organic cultivation of apples (Malus domestica Borkh.), for example, it was observed a good fruit 
bagging efficiency, avoiding the attack of some arthropods pests, especially fruit-flies Anastrepha fraterculus (Wiedemann) (Diptera: Tephritidae) and maintaining the appearance and the quality of the fruits, not altering the market price (Santos and Wamser, 2006).

The bagging of tomato inflorescence with TNT acted as a mechanical control to the attack of insects and did not alter their color (Santos et al., 2007). However, studies that involve fruit bagging technique have presented divergent results. Huang et al. (2009) working with pear fruits and Yang et al. (2009) with apples, both bagged in paper bags, reported reduction of titratable acidity of the fruits. On the other hand, apple fruits bagged with TNT were not affected on the titratable acidity content when compared to non-bagged fruits (Teixeira et al., 2011). In guavas, the TNT bagging favored the increase of weight of the fruits regardless the diameter in which they were bagged (Azevedo et al., 2016). Therefore, it is observed that the bagging technique may negatively or positively affect the fruits organoleptic quality.

Few the information regarding characteristics of fruits that develop by bagging and, mostly about the proper size of fruits for bagging, aiming to maximize the use of the technique without affecting their postharvest quality (Santos et al., 2013). This paper has as objective to assess the postharvest quality of 'Valerin' tomato fruits submitted to bagging with TNT on different fruit development periods, produced with/ without insecticides for pest control, and to determine the most appropriate phenological stage for bagging with less postharvest interference.

\section{MATERIAL AND METHODS}

\section{Experimental area}

The experiment was conducted in a 'Valerin' commercial tomato crop belonging to the salad group, of undetermined growth in a stacked system located on the "Jaburuna" District, "Ubajara", "Ceará" State (03 51'16" S and 40 55'16" W, altitude: $819 \mathrm{~m}$ ). This town is located on the "Serra da Ibiapaba" region, northwest of the "Ceará" State of Brazil, $320 \mathrm{~km}$ from the capital, "Fortaleza". Assessments related to the postharvest quality of the fruits were made on the Embrapa Tropical Agroindustry Postharvest Laboratory, "Fortaleza", "Ceará" State, Brazil.
The experiment was carried out between February and June of 2015. Plants were distributed in a $1.2 \times$ $0.6 \mathrm{~m}$ spacing. The staking method used was vertical with a narrow ribbon. All cultivation practices (transplanting, pruning, thinning, hilling fertilizing, etc.) were performed as recommended for the cultivation; irrigation was made through the dripping method (Filgueira, 2008).

The research was performed on two experimental areas, one treated with insecticides and other non-treated, both receiving the TNT bagging (TNTEX Embalagens, TNTEX Industria e Comercio Ltda., Fortaleza, CE, Brazil) at different phenological stages. These areas were selected inside a commercial orchard of staked tomato. Experimental outlining was in randomized blocks (Ensuring homogeneity of the experimental area) of $2 \times 4$ factorial scheme with five repetitions. Factors correspond to the employment of insecticides: 1- Plants treated with insecticides (utilization of chemical products and the pulverization calendar was determined by the producer, as what is commonly used in the region), and 2- Plants non-treated with insecticides; and the utilization of the TNT bag for bagging tomato bunches: T1- Bagging of the flower, T2- Bagging of fruits with $1.5 \mathrm{~cm}$, T3- Bagging of fruits with $3.0 \mathrm{~cm}$, non-bagged bunches (control)]. The used TNT g was white with $22 \times 18 \mathrm{~cm}$ dimensions, $17 \mathrm{~g}$ knitting and was closed with a rubber band. Each block was represented by a row of 20 plants, five from each treatment, aiming the bagging of fruits. For the insecticide evaluation, 100 plants per area were assessed.

All flowers and/or bunches were weekly marked for identification of the phenological stage of the bagged fruits, so that the harvest was homogeneous, in other words, fruits showing the same maturation time. Three harvests were made, the first one about $110 \mathrm{~d}$ after seeding, on 14/05/2015, the second on $21 / 05 / 2015$ and the last one on $28 / 05 / 2015$, as the fruits were reaching the same maturation point, identified by the development of color according to scale developed by Alvarenga (2004). Thirty fruits per treatment were harvested concerning the bagging season, 10 every harvest, being this set of fruits considered a sample unit. Harvested fruits were properly identified and transported on the next day to the Embrapa Tropical Agroindustry Postharvest Laboratory, where they were duly sanitized - washed in water and dried naturally at room temperature $\left(23^{\circ} \mathrm{C}\right)$ and $60 \%$ relative humidity - remaining in this condition 
inside in the plastic bags during the evaluations for the postharvest quality assessments.

\section{Fruit coloring}

Fruit coloring was determined on intact fruits using the colorimeter Minolta Chroma Meter CR 400b (Konica Minolta Sensing Europe B.V., UK), calibrated on a white porcelain surface, that expresses color on three parameters: L (Luminosity), $\mathrm{a}^{*}$ and $\mathrm{b}^{*}$, which allowed to calculate the Hue angle (color's angle; $0^{\circ}$ - red; $90^{\circ}$ - yellow; $180^{\circ}$ - green; $270^{\circ}$ - blue and $360^{\circ}$ - black) and the chroma (saturation or color's intensity; 0 -impure color and 60 - pure color). The Hue angle is equal to the [tangent $\left.\operatorname{arc}\left(\mathrm{b}^{*} / \mathrm{a}\right)\right]$ and the chroma is $\left[\left(a^{*} 2+b^{*} 2\right) 1 / 2\right]$, according to Minolta (2007).

\section{Fruit firmness}

Firmness was determined on intact fruits using a manual penetrometer, Magness-Taylor FT 011 model (Facchini Francesco Srl., Brescia, Italy) with an $8 \mathrm{~mm}$ tip diameter. Two readings were done on opposite sides of the equatorial portion of each fruit. Values were expressed in Newtown $(\mathrm{N})$.

\section{Total soluble solids (TSS)}

The pulp of the fruits was removed on the day after the harvest using a domestic centrifuge and conditioned inside properly identified jars and stored at $-20^{\circ} \mathrm{C}$ for further analysis. After filtering the pulp in a paper filter, the TTS content was determined through a digital refractometer, Atago $®$ PR-101 Pallete model (Atago Brazil Ltda., Ribeirão Preto-SP, Brazil, with scaling between 0 and 32 and automatic temperature compensation. The results were expressed in ${ }^{\circ} \mathrm{Brix}$ (AOAC, 1995).

\section{Total titratable acidity (TTA)}

Total titratable acidity was determined in duplicate using $1 \mathrm{~g}$ of pulp in $50 \mathrm{~mL}$ of distilled water and 3 drops of alcohol phenolphthalein at 1\% (AOAC, 1995). Next, titration with $\mathrm{NAOH} 0.1 \mathrm{M}$ solution was made until obtained the permanent light pink coloration, being the results expressed on percentage of citric acid.

\section{Measurement of $\mathrm{pH}$}

The $\mathrm{pH}$ was determined directly on the pulp through a digital potentiometer Mettler DL 12 model (Mettler-Toledo, Sao Paulo, Brazil) with automatic temperature adjustment and glass membrane, duly standardized with buffer solutions $\mathrm{pH} 7.0$ and $\mathrm{pH}$ 4.0 , as the recommended methodology of AOAC (1995).

\section{Determining pigmentation}

The lycopene, the $ß$-carotene and total carotenoids were determined by the Lime et al. (1957) method with the Moretti et al. (1998) proposed modifications. In a $125 \mathrm{~mL}$ Erlenmeyer were placed $4 \mathrm{~g}$ of pulp and $20 \mathrm{~mL}$ of acetone, followed by 1 -min agitation in ULTA-TURRAX. Proceeded to the vacuum filtering, on a Whatmann number 4 paper filter, with aid of a conical flask protected with aluminum paper in order to avoid photo oxidation of the pigments.

After filtering, the flask which the tissue was homogenized twice was washed with $12.5 \mathrm{~mL}$ of acetone. To the result of what was filtered $22.5 \mathrm{~mL}$ of hexane was added. The content was then transferred to a separation funnel of $125 \mathrm{~mL}$ involved in aluminum. It was laid to rest for $30 \mathrm{~min}$ after a clear phase separation, followed by the washing of the material with $50 \mathrm{~mL}$ of distilled water. This operation was repeated three times.

After the final wash, the pigments-hexane extract was transferred to a volumetric flask of $50 \mathrm{~mL}$ where the volume was completed with hexane. Reading of the extract was done in a spectrophotometer with wave-lengths: $503 \mathrm{~nm}$ (maximum of absorption for lycopene) and $451 \mathrm{~nm}$ (maximum of absorption for B-carotene and close to the minimum for lycopene).

Total carotenoid concentration $\left(\mathrm{mg} \mathrm{kg}^{-1}\right)$ was calculated using the following equation:

$C t=1 /$ b.c $\left(395 . A_{503}-80.5 \cdot A_{451}\right)$

where Ct: total carotenoid concentration (mg/100g); $\mathrm{A}_{503 / 451}$ : pigment absorption at 503 and $451 \mathrm{~nm}$; b: path followed by the light inside the cuvette $(b=$ $1 \mathrm{~cm})$; and c: pigment-hexane extract concentration $\left(\mathrm{g} \mathrm{L}^{-1}\right)$. 
The results were expressed in $\mathrm{mg} / 50 \mathrm{~g}$ of the pulp's fresh mass. To calculate the $ß$-carotene and lycopene concentration the constants on the formula above were calculated using $B$-carotene specific absorbance at $451 \mathrm{~nm}$ (250.3) and $503 \mathrm{~nm}$ (51.0), and lycopene's at $451 \mathrm{~nm}$ (195.5) and 503 (292.7).

\section{Statistical analyses}

Statistical analyses were carried out with program SASM-Agri version 8.2 (Canteri et al., 2001). Data were analyzed by factorial ANOVA. Multiple comparisons were conducted using Duncan's multiple range tests at a significance level of 0.05 . The lycopene and total soluble solids variables were transformed in [Root of $(x+0.5)]$ for processing of the analyses.

\section{RESULTS}

There was no interaction between the pulverization and fruit bagging factors to none of the variables, thus, factors were analyzed in isolation (Tab. 1 and 2). Luminosity, hue angle and firmness were influenced by the utilization of TNT bags (Tab. 1).

Bagged fruits with 1.5 and $3.0 \mathrm{~cm}$ diameter presented smaller luminosity values and hue angle (Tab. 1). On the other hand, when bagging was performed during the flower phase those variables did not differ from the bagged plants (Tab. 1). Regarding firmness, bagged fruits with $3.0 \mathrm{~cm}$ presented less firmness than those non-bagged or bagged during the flower phase (Tab. 1).

Chromaticity, $\mathrm{pH}$ and TTA variables were influenced by the pulverization (Tab. 1 and 2). Pulverized fruits with insecticide spray presented greater chromaticity, $\mathrm{pH}$ and smaller TTA, when compared to non-pulverized fruits (Tab. 1 and 2 ). The $\mathrm{pH}$ values obtained were inside the 4.7 and 4.6 range, while titratable acidity was from 0.40 to $0.42 \%$ of citric acid for pulverized and non-pulverized fruits, respectively (Tab. 2). Total soluble solids, total carotenoid, $ß$-carotene and lycopene variables did not present significant difference to none of the factors (Tab. 2).

\section{DISCUSSION}

The characteristic color of a fruit epidermis is one of the main criteria for consumer acceptance or rejection, indicating maturation degree (Jordão and Nakano, 2002). The colorimetry has been used to characterize the color of different pigments, for example, anthocyanins and carotenoids (predominant in tomato) (Paula et al., 2015). Bagged fruits (1.5

Table 1. Luminosity (LM), chromaticity (CR), hue angle (HA), firmness (FS) of 'Valerin' tomato fruits submitted to TNT bagging at different phenological stages, “Ubajara", “Ceará" State, Brazil, 2015.

\begin{tabular}{|c|c|c|c|c|c|c|}
\hline \multirow{2}{*}{\multicolumn{2}{|c|}{ Variables }} & \multicolumn{4}{|c|}{ Treatments: bagging seasons (means \pm standard error) } & \multirow{3}{*}{$\begin{array}{c}\text { Mean } \\
58.43 \pm 0.75\end{array}$} \\
\hline & & \multirow{2}{*}{$\begin{array}{c}\text { Flower } \\
59.70 \pm 1.00\end{array}$} & \multirow{2}{*}{$\frac{1.5 \mathrm{~cm}}{57.59 \pm 0.00}$} & \multirow{2}{*}{$\begin{array}{c}3.0 \mathrm{~cm} \\
56.65 \pm 1.00\end{array}$} & \multirow{2}{*}{$\begin{array}{c}\text { Non-bagged } \\
59.78 \pm 1.00\end{array}$} & \\
\hline \multirow{3}{*}{ LM ( $\left.{ }^{\circ} h\right)$} & $P^{(1)}$ & & & & & \\
\hline & $N P^{(2)}$ & $58.07 \pm 1.00$ & $56.81 \pm 1.00$ & $57.53 \pm 1.00$ & $58.64 \pm 0.00$ & $57.76 \pm 0.75$ \\
\hline & Mean & $58.89 \pm 1.00 a b$ & $57.20 \pm 0.50 \mathrm{~b}$ & $57.09 \pm 1.00 \mathrm{~b}$ & $59.21 \pm 0.50 \mathrm{a}$ & - \\
\hline \multirow{3}{*}{$\mathrm{CR}\left({ }^{\circ} \mathrm{h}\right)$} & $P$ & $39.26 \pm 1.13$ & $38.42 \pm 0.45$ & $39.16 \pm 0.53$ & $39.05 \pm 0.49$ & $38.97 \pm 0.65 \mathrm{~A}$ \\
\hline & NP & $37.81 \pm 0.49$ & $37.65 \pm 0.58$ & $37.71 \pm 0.43$ & $38.23 \pm 0.46$ & $37.85 \pm 0.49 \mathrm{~B}$ \\
\hline & Mean & $38.54 \pm 0.81$ & $38.03 \pm 0.51$ & $38.44 \pm 0.48$ & $38.64 \pm 0.47$ & - \\
\hline \multirow{3}{*}{$\mathrm{HA}\left({ }^{\circ} h\right)$} & $P$ & $98.14 \pm 6.63$ & $90.20 \pm 2.31$ & $85.19 \pm 4.7$ & $100.6 \pm 2.52$ & $93.55 \pm 4.04$ \\
\hline & NP & $91.60 \pm 2.28$ & $87.48 \pm 4.14$ & $88.99 \pm 3.67$ & $97.27 \pm 3.87$ & $91.34 \pm 3.49$ \\
\hline & Mean & $94.87 \pm 4.45 a b$ & $88.84 \pm 3.22 b$ & $87.09 \pm 4.18 b$ & $98.97 \pm 3.19 \mathrm{a}$ & - \\
\hline \multirow{3}{*}{ FS (N) } & $\mathrm{P}$ & $72.54 \pm 3.04$ & $68.28 \pm 2.06$ & $65.71 \pm 1.39$ & $70.61 \pm 2.82$ & $69.28 \pm 2.33$ \\
\hline & NP & $67.85 \pm 1.53$ & $71.09 \pm 1.98$ & $67.06 \pm 1.38$ & $73.85 \pm 1.73$ & $69.96 \pm 1.65$ \\
\hline & Mean & $70.19 \pm 2.28 \mathrm{a}$ & $69.68 \pm 2.02 a b$ & $66.38 \pm 1.38 b$ & $72.23 \pm 2.27 \mathrm{a}$ & - \\
\hline
\end{tabular}

Means followed by the same lowercase letter on the column do not differ among themselves by the $\mathrm{F}$ test $(P \leq 0.05)$; means followed by the same lowercase letter on the line do not differ among themselves by the Duncan test $(P \leq 0.05)$; ${ }^{(1)} \mathrm{P}$ : associated to insecticide pulverization; ${ }^{(2)} \mathrm{NP}$ : without insecticide pulverization. 


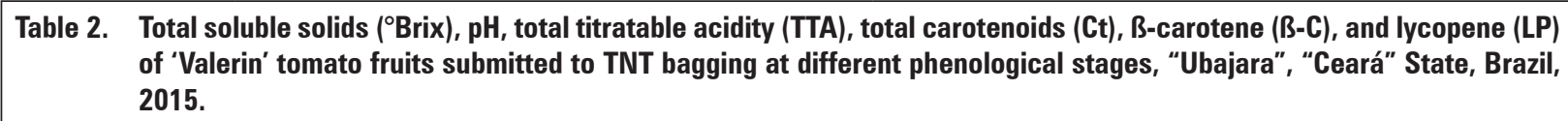

\begin{tabular}{|c|c|c|c|c|c|c|}
\hline \multirow{2}{*}{\multicolumn{2}{|c|}{ Variables }} & \multicolumn{4}{|c|}{ Treatments: Bagging season (means \pm standard error) } & \multirow{3}{*}{$\begin{array}{c}\text { Means } \\
4.57 \pm 0.24\end{array}$} \\
\hline & & \multirow{2}{*}{$\begin{array}{c}\text { Flower } \\
4.45 \pm 0.31\end{array}$} & \multirow{2}{*}{$\frac{1.5 \mathrm{~cm}}{4.60 \pm 0.24}$} & \multirow{2}{*}{$\frac{3.0 \mathrm{~cm}}{4.67 \pm 0.19}$} & \multirow{2}{*}{$\frac{\text { Non-bagged }}{4.55 \pm 0.22}$} & \\
\hline \multirow{3}{*}{${ }^{\circ}$ Brix } & $P^{(1)}$ & & & & & \\
\hline & $N P^{(2)}$ & $4.17 \pm 0.27$ & $6.05 \pm 1.85$ & $4.02 \pm 0.23$ & $4.27 \pm 0.2$ & $4.63 \pm 0.64$ \\
\hline & Mean & $4.31 \pm 0.29$ & $5.32 \pm 1.04$ & $4.35 \pm 0.21$ & $4.41 \pm 0.21$ & - \\
\hline \multirow{3}{*}{ pH } & $P$ & $4.69 \pm 0.02$ & $4.64 \pm 0.03$ & $4.68 \pm 0.02$ & $4.63 \pm 0.02$ & $4.66 \pm 0.02 \mathrm{~A}$ \\
\hline & NP & $4.57 \pm 0.04$ & $4.55 \pm 0.02$ & $4.59 \pm 0.02$ & $4.55 \pm 0.02$ & $4.57 \pm 0.02 \mathrm{~B}$ \\
\hline & Mean & $4.63 \pm 0.03$ & $4.60 \pm 0.02$ & $4.63 \pm 0.02$ & $4.59 \pm 0.02$ & - \\
\hline \multirow{3}{*}{ TTA (\% citricacid) } & $P$ & $0.38 \pm 0.01$ & $0.42 \pm 0.01$ & $0.41 \pm 0.01$ & $0.40 \pm 0.01$ & $0.40 \pm 0.01 \mathrm{~B}$ \\
\hline & NP & $0.43 \pm 0.01$ & $0.42 \pm 0.02$ & $0.41 \pm 0.02$ & $0.43 \pm 0.01$ & $0.42 \pm 0.01 \mathrm{~A}$ \\
\hline & Mean & $0.40 \pm 0.01$ & $0.42 \pm 0.01$ & $0.41 \pm 0.01$ & $0.41 \pm 0.01$ & - \\
\hline \multirow{3}{*}{$\mathrm{Ct}^{\mathrm{ns}}$} & $P$ & $0.34 \pm 0.08$ & $0.40 \pm 0.07$ & $0.38 \pm 0.04$ & $0.38 \pm 0.07$ & $0.37 \pm 0.06$ \\
\hline & NP & $0.37 \pm 0.04$ & $0.44 \pm 0.07$ & $0.50 \pm 0.08$ & $0.42 \pm 0.04$ & $0.43 \pm 0.06$ \\
\hline & Mean & $0.35 \pm 0.06$ & $0.42 \pm 0.07$ & $0.44 \pm 0.06$ & $0.40 \pm 0.05$ & - \\
\hline \multirow{3}{*}{ ß-carotenen ${ }^{\text {ns }}$} & $P$ & $0.41 \pm 0.05$ & $0.40 \pm 0.04$ & $0.41 \pm 0.02$ & $0.41 \pm 0.02$ & $0.41 \pm 0.03$ \\
\hline & NP & $0.44 \pm 0.03$ & $0.35 \pm 0.04$ & $0.41 \pm 0.04$ & $0.40 \pm 0.04$ & $0.40 \pm 0.04$ \\
\hline & Mean & $0.42 \pm 0.04$ & $0.37 \pm 0.04$ & $0.41 \pm 0.03$ & $0.40 \pm 0.03$ & - \\
\hline \multirow{3}{*}{ Lycopene $^{\text {ns }}$} & $P$ & $0.09 \pm 0.02$ & $0.09 \pm 0.02$ & $0.08 \pm 0.01$ & $0.12 \pm 0.03$ & $0.10 \pm 0.02$ \\
\hline & NP & $0.11 \pm 0.04$ & $0.12 \pm 0.02$ & $0.13 \pm 0.02$ & $0.10 \pm 0.03$ & $0.11 \pm 0.03$ \\
\hline & Mean & $0.10 \pm 0.03$ & $0.11 \pm 0.02$ & $0.10 \pm 0.01$ & $0.11 \pm 0.03$ & - \\
\hline
\end{tabular}

Means followed by the same letter on the column do not differ among themselves through the $\mathrm{F}$ test $(P \leq 0.05)$; ${ }^{\text {ns }}$ Non-significant; ${ }^{(1)} P$ : associated to insecticide pulverization; ${ }^{(2)}$ NP: without insecticide pulverization.

and $3.0 \mathrm{~cm}$ ) presented coloration between red and yellow, while the non-bagged and those bagged during the flower phase presented coloration between yellow and green.

Alteration observed on the 'Valerin' tomato fruits coloration submitted to bagging with TNT might have occurred due to the microclimate formed inside the casing. The bagging of fruits promotes an increase of temperature inside the casing, changing, thus, the microenvironment of fruit development, promoting alterations on quality and anticipating fruit maturation (Wang et al., 2007). Teixeira et al. (2011) assessing the use of transparent microperfurated polypropylene plastic bags and TNT sacks for bagging apple fruits as control method for the main cultivation pests, verified that on both packings the temperature inside the bags was $25.0^{\circ} \mathrm{C}$, while for non-bagged fruits was $22.0^{\circ} \mathrm{C}$.

Despite the temperature variation inside the TNT bag was not evaluated on this study, the possible change of microclimate inside the casing might have stimulated the early ethylene production, provoking biochemical alterations on the fruit, promoting coloration and firmness alteration. The main effect of ethylene on horticultural products is to induce an increase of respiratory activity, increasing the metabolic activity, anticipating its development. Besides, the TNT bagging might have made difficult the ethylene dissipation, focusing it around the fruit and favoring its action on the maturation process (Chitarra and Chitarra, 2005). Despite the differences of materials used for bagging, this report was also observed in peaches (Prunus persica) bagged with polyethylene plastic bags (Silva et al., 2014).

Tomatoes with a less reddish coloration are identified, by the consumers, as the firmness, while those with a more reddish coloration are presented less firm (Batu, 2004). An important trait for tomato commercialization is the fruit firmness maintenance. Therefore, 'Valerin' tomato fruits may be bagged during the flower phase and/or with $1.5 \mathrm{~cm}$ diameter, 
as bagging on these stages do not alter their firmness, being similar to non-bagged fruits. The consumer expects that the tomato fruits, regardless the cultivar, are firm to the tact and not easily deformed (Suslow and Cantwell, 2003).

Bagging, when done at the beginning of the growth phase (flower and $1.5 \mathrm{~cm}$ diameter) probably contributed with its adaptation to new temperature conditions related to bagging, differently of what might have happened with fruits bagged with $3.0 \mathrm{~cm}$ diameter. The possible temperature increase inside the sacks could have promoted an increase of the respiratory rate and a consequent increase of the activity of the hydrolytic enzymes pectin methyl esterase (PME) and polygalacturonase (PG), that act to reduce fruit firmness (Fachin, 2003). In this sense, the firmness results, like the coloration ones, demonstrate the importance of the phase of development of the fruit to decide the proper moment to bag, without interfering on the final quality of the product.

The tomato fruit maturation involves physiological, biochemical and molecular changes, including chlorophyll degradation and carotenoid synthesis and storage, particularly lycopene (López-Juez, 2007). The use of TNT bags as a mechanical barrier kept the chemical characteristics of the 'Valerin' tomato fruits such as: total soluble solids, $\mathrm{pH}$, titratable acidity, total carotenoids, $ß$-carotene and lycopene similar to those non-bagged fruits. This is due to the fact that the characteristics of the TNT bags used (Jordão and Nakano, 2002) or even intrinsic of the cultivar. The content of soluble solids is one of the fruits main characteristics concerning taste, since it is on this portion that sugars and acids are found. The TTS content is also an indicative of the fruits quality and its byproducts (Shirahige et al., 2010). In table tomato cultivars, such as 'Raisa' and 'Santa Clara', the total soluble solid content varied between 4.4 and $6.0 \%$ (Ferreira et al., 2010) being compatible to those obtained on the present study.

The highest $\mathrm{pH}$ and TTA observed on treated (pulverized) fruits, compared to non-pulverized, despite significant differences, was not enough to affect the final quality of the products, since this difference was on the 0.01 scale for $\mathrm{pH}$ and $2.0 \%$ for TTA. The obtained $\mathrm{pH}$ and TTA acidity ranges on this study are similar to those described by Rodrigues et al. (2008) - 4.20 to 4.68 - and Stevens and Rick (1986) - 0.40 to $0.91 \%$ of citric acid. These values are inside the variation range that is considered ideal for quality tomatoes (Guilherme et al., 2014). The existing variations among $\mathrm{pH}$ and fruits acidity may be explained by the genetic factor, since each cultivar represents a different chemical constitution (Seleguini et al., 2007).

In order to be a tool for plague handling, exogenous additives or bagging must not interfere on the product final quality (Lebedenco et al., 2007; Pereira et al., 2009; Laiton et al., 2012). Thus, attributes related to taste as $\mathrm{pH}$, TTA, TSS content, among others, must be kept aiming to answer the expectations of the consumer.

\section{CONCLUSION}

The bagging of 'Valerin' tomato bunches with TNT sacks, when performed during the flower phase or when the fruits present about $1.5 \mathrm{~cm}$ diameter does not alter the fruits postharvest quality parameters, regardless of the use or not of chemical insecticides.

\section{ACKNOWLEDGMENTS}

To Antônio Severino Chaves, rural producer, for providing the experimental area; Conselho Nacional de Desenvolvimento Científico e Tecnológico (CNPq), Coordenação de Aperfeiçoamento de Pessoal de Nível Superior (CAPES), Fundação Cearense de Apoio ao Desenvolvimento Científico e Tecnológico (FUNCAP) and TNTEX Embalagens represented by Mário R. Mezzedimi for the scholarships and funding granted.

\section{REFERENCES}

Alvarenga, M.A.R. 2004. Tomate: produção em campo, casa-de-vegetação e em hidroponia. UFLA, Lavras, Brazil.

AOAC International. 1995. Official methods of analysis of AOAC International. $16^{\text {th }} \mathrm{ed}$. Association of Analytical Communities, Arlington, VA.

Azevedo, F.R., D.R. Nere, C.A.M. Santos, E.S. Moura, and R. Azevedo. 2016. Efeito do ensacamento sobre a incidência de moscas-das-frutas e na qualidade das goiabas. Arq. Inst. Biol. 83, 1-8.

Batu, A. 2004. Determination of acceptable firmness and colour values of tomatoes. J. Food Eng. 61, 471-475. Doi: 10.1016/S0260-8774(03)00141-9

Canteri, M.G., R.A. Althaus, J.S. Virgens-Filho, E.A. Giglioti, and C.V. Godoy. 2001. SASM - Agri: Sistema para 
análise e separação de médias em experimentos agrícolas pelos métodos Scoft - Knott, Tukey e Duncan. Rev. Bras. Agrocomp. 1(2), 18-24.

Chitarra, M.I.F. and A.B. Chitarra. 2005. Pós-colheita de frutas e hortaliças: Fisiologia e manuseio. $2^{\text {nd }}$ ed. UFLA, Lavras, Brazil.

Fachin, D. 2003. Temperature and pressure in activation of tomato pectinases: a kinetic study. Ph.D. thesis. Katholieke Universiteit Leuven, Belgium.

Ferreira, S.M.R., D.A. Quadros, E.N.L. Karkle, J.J. Lima, L.T. Tullio y R.J.S. Freitas. 2010. Qualidade pós-colheita do tomate de mesa convencional e orgânico. Ciênc. Tecnol. Aliment. 30(4), 858-864. Doi: 10.1590/ S0101-20612010000400004

Filgueira, F.A.R. 2008. Novo manual de olericultura: Agrotecnologia moderna na produção e comercialização de hortaliças. $3^{a}$ ed. Ed. UFV, Viçosa-MG, Brazil.

Filgueiras, R.M.C., P.L. Pastori, F.F. Pereira, C.R. Coutinho, S.O. Kassab, and L.C.M. Bezerra. 2017. Agronomical indicators and incidence of insect borers of tomato fruits protected with non-woven fabric bags. Ciênc. Rural. 47(6), e20160278. Doi: 10.1590/0103-8478cr20160278

Guilherme, D.O., L. Pinho, T.F.M. Cavalcanti, C.A. Costa, and A.C. Almeida. 2014. Análise sensorial e físico-química de frutos tomate cereja orgânicos. Rev. Caatinga. 27(1), 181-186.

Herrera, H.J., A. Hurtado-Salazar, and N. Ceballos-Aguirre. 2015. Estudio técnico y económico del tomate tipo cereza élite (Solanum lycopersicum L. var. cerasiforme) bajo condiciones semicontroladas. Rev. Colomb. Cienc. Hortic. 9(2), 290-300. Doi: 10.17584/ rcch.2015v9i2.4185

Huang C., B. Hu, Y. Teng, J. Su, O. Shu, Z. Cheng y L. Zeng. 2009. Effects of fruit bagging on coloring and related physiology and qualities of red Chinese sand pears during fruit maturation. Sci. Hortic. 121, 149-158. Doi: 10.1016/j.scienta.2009.01.031

Jordão, A.L. and Nakano, O. 2002. Ensacamento de frutos do tomateiro visando ao controle de pragas e à redução de defensivos. Sci. Agric. 59(2), 281-289. Doi: 10.1590/ S0103-90162002000200012

Laiton, P., A. Giovanni, P.J. Almanza-Merchán, and H.E. Balaguera-López. 2012. Producción y calidad poscosecha de tomate (Solanum lycopersicum L.) larga vida sometido a la aplicación de ácido giberélico. Rev. Colomb. Cienc. Hortic. 6(2), 183-195. Doi: 10.17584/ rcch.2012v6i2.1976

Leite, G.L.D., A. Fialho, J.C. Zanuncio, R. Reis Júnior, and C.A. Costa. 2014. Bagging tomato fruits: A viable and economical method of preventing diseases and insect damage in organic production. Fla. Entomol. 97(1), 50-60. Doi: 10.1653/024.097.0106
Lebedenco A., A.M. Auad, and S.N. Kronka. 2007. Métodos de controle de lepidópteros do tomateiro (Lycopersicon esculentum Mill.). Acta. Sci. Agron. 29(3), 339-344. Doi: 10.4025/actasciagron.v29i3.278

Lime, B.J., F.P. Griffiths, R.T. O’Connor, D.C. Heinzelmann, and E.R. McCall. 1957. Spectrophotometric methods for determining pigmentation - beta-carotene and lycopene - in ruby red grapefruit. J. Agric. Food. Chem. 5(12), 941-944. Doi: 10.1021/jf60082a008

López-Juez, E. 2007. Plastid biogenesis, between light and shadows. J. Exp. Bot. 58(1), 11-26. Doi: 10.1093/jxb/ erl196

Minolta. 2007. Precise color communication: color control from perception to instrumentation. Minolta Co. Ltda., Osaka, Japan.

Moretti, C.L., S.A. Sargent, D.J. Huber, A.G. Calbo, and R. Puschmann. 1998. Chemical composition and physical properties of pericarp, locule and placental tissues of tomatoes with internal bruising. J. Amer. Soc. Hort. Sci. 123(4), 656-660.

Paula, J.T., J.T.V. Resende, M.V. Faria, A.S.T. Figueiredo, K. Schwarz, and E.R. Neumann. 2015. Características físico-químicas e compostos bioativos em frutos de tomateiro colhidos em diferentes estádios de maturação. Hortic. Bras. 33(4), 434-440. Doi: 10.1590/ S0102-053620150000400005

Pereira, M.C.T., N. Bandeira, R.C. Antunes Júnior, S. Nietsche, M.X. Oliveira Júnior, C.D. Alvarenga, T.M. Santos, and J.R. Oliveira. 2009. Efeito do ensacamento na qualidade dos frutos e na incidência da broca-dos-frutos da atemoieira e da pinheira. Bragantia 68(2), 389396. Doi: 10.1590/S0006-87052009000200013

Pinheiro, A.C.M., B. Vilas, A.D.P. Alves, and M. La Selva. 2007. Amadurecimento de bananas 'Maçã' submetidas ao 1-metilciclopropeno (1-MCP). Rev. Bras. Frutic. 29(1), 1-4. Doi: 10.1590/S0100-29452007000100003

Rodrigues, M.B., A.L.C. Dornelles, S.A. Oliveira, M.R.J. Moraes, F.J. Lisboa, D.A.G. Silva, and M.B. Pereira. 2008. Características físico-químicas de frutos de 25 cultivares de tomateiro tipo cereja. Hortic. Bras. 26(2), 5463-5466.

Santos, H.A.A., M.I.C. Boff, P. Boff, C.R. Franco, A.I. Orth, and R.O. Nodari. 2013. Determinação de épocas de ensacamento de frutos de goiabeira-serrana para exclusão da mosca-das-frutas. Cuad. Agroecol. 8(2), 1-5.

Santos, J.P. and A.F. Wamser. 2006. Efeito do ensacamento de frutos sobe danos causados por fatores bióticos em pomar orgânico de macieira. Rev. Bras. Frutic. 28(2), 168-171. Doi: 10.1590/S0100-29452006000200003

Santos, J.P., A.F. Wamser, W.F. Becker, and S. Mueller. 2007. Influência do ensacamento das inflorescências de tomate no controle de insetos-praga e na cor dos frutos. Hortic. Bras. 25(1), 1-4. 
Seleguini, A., S. Seno, and M.J.A. Faria Júnior. 2007. Híbridos de tomateiro industrial cultivados em ambiente protegido e campo aberto. Científica 35(1), 80-87. Doi: 10.15361/1984-5529.2007v35n1p80+-+87

Shirahige, F.H., M.T.R. Arlete, L.F.V. Purquerio, C.R.L. Carvaho, and P.C.T. Melo. 2010. Produtividade e qualidade de tomates Santa Cruz e Italiano em função do raleio de frutos. Hort. Bras. 28(3), 292-298. Doi: 10.1590/ S0102-05362010000300009

Silva, D.F., A.A. Alvarenga, F. Villa, and A.J.B. Lima. 2014. Ensacamento de frutos sobre a qualidade e produtividade de novas cultivares e seleções de pêssego no sul de Minas Gerais. Rev. Agrar. 7(26), 530-540.

Stevens, M.A. and C.M. Rick. 1986. Genetics and breeding. pp. 35-110. In: Atherton, J.G. and J. Rudich (eds.). The tomato crop: A scientific basis for improvement. Chapman and Hall, London, UK.
Suslow, T.V. and M. Cantwell. 2003. Tomate: (Jitomate). Recomendaciones para mantener la calidad post cosecha. Department of Vegetable Crops, University of California, Davis, CA.

Teixeira, R., M.I.C. Boff, C.V.T.A. Amarante, C.A. Steffens, and P. Boff. 2011. Efeito do ensacamento dos frutos no controle de pragas e doenças e na qualidade e maturação de maçãs 'Fuji Suprema'. Bragantia 70(3), 688-695. Doi: 10.1590/S0006-87052011000300027

Yang, H.W., C.X. Zhu, H.J. Bu, B.G. Hu, C.H. Wang, and C.X. Huang. 2009. Effect of bagging on fruit development and quality in cross- winter of-season longan. Sci. Hortic. 120. 194-200. Doi: 10.1016/j. scienta.2008.10.009

Wang, L., K. Xu, F. Bei, and F.S. Gao. 2007. Effects of bagging on the microenvironment, yield and quality of over-wintering tomato. Chin. J. Appl. Ecol. 18, 837-842. 